\title{
Mediating Effect of Motivation on Employees Performance in Private Equity Firms, Kenya
}

\author{
Ngari Evelyne ${ }^{1,}$, ,Stephen Muathe ${ }^{2}$, James Kilika ${ }^{2}$ \\ ${ }^{1}$ Department of Human Resource Management, Kenyatta University, Nairobi, Kenya \\ ${ }^{2}$ Department of Business Administration, Kenyatta University, Nairobi, Kenya
}

Email address:

wambuievelyne@yahoo.com (N. Evelyne)

${ }^{*}$ Corresponding author

\section{To cite this article:}

Ngari Evelyne, Stephen Muathe, James Kilika. Mediating Effect of Motivation on Employees Performance in Private Equity Firms, Kenya. Journal of Human Resource Management. Vol. 6, No. 2, 2018, pp. 78-84. doi: 10.11648/j.jhrm.20180602.15

Received: July 12, 2018; Accepted: August 22, 2018; Published: September 21, 2018

\begin{abstract}
Organizations are always in pursuit of finding ways to enhance their performance. One of the ways is to enhance employee performance by incorporating job characteristics that contribute to employee motivation, satisfaction and commitment of the employees. The job characteristics necessary for better performance of employees are skill variety, task identity, task significance, autonomy and feedback. The purpose of this study was to determine the effect of job characteristics on the performance of employees among Private Equity Firms in Nairobi City County in Kenya. The specific objectives of the study were to determine the effect of skill variety, task identity, task significance, autonomy and feedback on employee performance among private equity firms in Nairobi City County, Kenya. The study also sought to determine the mediating effect of employee motivation on the relationship between job characteristics and the performance of employees among private equity firms. The theories used in the study were the Job Characteristics model, Herzberg's two-factor theory and the Demand control model. The study adopted a descriptive research design and involved a census of all 210 employees in 25 different private equity firms in Nairobi City County, Kenya. Questionnaires were used for primary data collection. To ascertain the validity and reliability of the questionnaire, a pre-test was conducted on one of the private equity firms where the cut-off for Cronbach alpha was taken as a value of 0.7 and the aggregate alpha value in this study was 0.755 . The quantitative data in the study was analysed using descriptive and inferential statistics. Descriptive analysis comprising the mean, frequency, percentage and standard deviation while inferential statistics was stepwise multiple regression. The Statistical Package for Social Sciences (SPSS) was used to conduct the analysis. 116 questionnaires out of the 210 distributed were used for analysis, which translates to $55 \%$ of the response rate which was adequate for the study. From the findings, variety of skills, task identity, autonomy and feedback were found to affect the performance of employees, while task significance did not significantly affect employee performance. The results also indicated partial mediation by the mediator on the independent variable. The study recommends that Job characteristics be considered in planning and evaluation of employees' jobs and performance respectively. Increased freedom in decision making and job rotation were cited as some of the ways in which the Private Equity Firms could increase employees' motivation, hence their performance.
\end{abstract}

Keywords: Autonomy, Employee Performance, Feedback, Skill Variety, Task Identity, Task Significance

\section{Introduction}

Performance in organizations relies on the deployment of Human Resource Management (HRM) strategies that are successful in attracting, developing and retaining a highly engaged and committed personnel [3]. The deployment of a highly engaged personnel is expected to drive an excellent operations system to be a firm basis for performance. The engagement of staff is a matter that requires the design of jobs in a way that will arouse staff motivation. According to Armstrong the job characteristics model is one way of designing jobs based on their characteristics [4].

Hackman \& Oldham indicated that a connection of the characteristics of a job and employees' emotional and behavioral responses consists of three critical psychological 
states which include experienced responsibility, knowledge of results and experienced meaningfulness [12]. Jobs which have the best characteristics improve employees' motivation, satisfaction and dedication to work and also contribute to improvement of productivity in an organization hence eradicating some health issues while at the same time not having an impact on the morals and passion of the employees at work [6].

Skill variety as a job characteristic shows the range of skills required to complete a particular piece of work that leads to the desired individual and job results. Task identity is the rate at which a piece of work must be completed as one, by carrying out a particular piece of work from the beginning to the end with and end product that can be seen. Task significance on the other hand reflects the rate of influence of the job to the organization and play a vital role on the job and livelihood of other employees and those without the organization [16]. Autonomy is the rate at which work provides substantial freedom, discretion and independence to the worker [28]. Feedback from the particular work must offer explicit information to the staff about the usefulness of their work output and also allows them to monitor their individual progress towards the organizational goals and gives back information about their work outcome [11].

Employee motivation is defined by first understanding the meaning and the association between drives, needs, and incentives [22]. Miner, Ebrahimi \& Wachtel explained that in a system, motivation consists of these three key and intertwined elements which are drives, needs and incentives [23]. Supervisors as well as management scholars always thought that performance of employees is unachievable with no devotion to their work. In addition, employee motivation is a psychological characteristic that stimulates the degree of employee's commitment [2]. In this study, motivation is explained by the factors that inspire human behavior in a particular direction.

According to Adeyemo, there are several general expectations of motivation practices by supervisors. First, the common assumption that motivation is a good feeling and that one cannot have the good feeling about themselves if they are not motivated. Second, employee motivation is a feature that contributes to the employee performance [2]. Third, supervisors and scholars both make the assumption that motivation is not in adequate supply and need to be replenished from time to time. Finally, motivation is considered as avenue where supervisors may utilize the companies. If the supervisors know what motivates the staff, then they can tailor make tasks and rewards to match that which would make the staff "tick." In this regard, the job characteristics of different assignments come to the fore and could immensely determine how employees perform. Employee motivation may also be considered as that which it takes to inspire staff to perform by gratifying or satisfying to their needs.

Employee motivation in the context of job characteristics is an aspect that looks into how jobs impact on the psychological states of employees who have been assigned different organizational tasks based on skill variety, task identity, task significance, autonomy and feedback. Supervisors think that fringe benefits, rewards in form of money including salary are always considered the most important by workers. Employee thinking is an immense limitation for supervisors to come up with a standard assumption since all employees behave, perform and achieve in various ways [24]. The psychological and physiological states enabled by the job characteristics create a level of motivation, commitment and satisfaction.

Past studies show that employee participation in processing of information, making decisions and solving problems is positively related to motivation, contentment and efficiency, satisfaction and hence good performance of employees [25, 29, 31]. Employees who are motivated pay great attention to their work and make the work part of their lives. They also organizational goals as their own goals and always feel happy and satisfied whenever the goals are achieved [27]. A job that fully utilizes job characteristics leads to employee motivation, satisfaction and commitment. Outcomes of an effectively designed job that incorporates the five job characteristics are motivation, engagement, dedication and fulfilment that then leads to betterment of the employees' performance and the attainment of set goals [7].

The European Venture Capital Association (EVCA) (2007) defines Private Equity (PE) as the process of providing equity capital in form of money in the medium or long term to companies that are not quoted but have a high potential for growth. According to the Private Equity Annual Report of 2014, PE funds make their money by undoubtedly convincing the holders of the capital to give their large portions of money and charge a certain percentage of these to generate the return on investment (ROI). According to Deloitte fund managers in Kenya are quite optimistic and argue that the market is improving while mobilization of local funds and experts in diaspora are returning to the country [9].

However, this growth can only be achieved when the challenges of performance within the PE firms are overcome. Kathurima \& Kipanga, found that PE firms are grappling with such challenges as redundancy, profit reduction and high employee turnover [18]. Designing jobs in a balanced manner so as to encompass all the five characteristics namely skill variety, task identity, task significance, autonomy and feedback remains a topic that receives little interest from employers and policymakers as a driver of performance compared with other aspects of management such as leadership or management style [27]. On the other hand, Gatauwa suggested that lack of awareness is the key challenge in Private Equity in Kenya because it is a relatively new concept and little research has been done regarding job characteristics in the industry [10]. These challenges affect performance of the PE firms, which is a reflection of the actual performance of the employees.

The general objective of the study therefore, was to determine the effect of job characteristics on the performance of employees and the effect of motivation on this relationship 
among private equity firms in Nairobi City County in Kenya. This study is significant to human resource practitioners and policy makers to offer guidelines on how to incorporate job characteristics that retain a well-motivated and productive workforce. Human resource consultants and researchers will add to their knowledge in training employers and those concerned with the employees welfare while offering new knowledge for further research. They could also be informed on issues that influence employee performance thus assisting them during employee training and coaching sessions, conducting job analysis and evaluation on behalf of their clients. Academicians who would want to carry out further research will be informed by the study as it seeks to close the gaps cited in previous studies. These gaps include small sample sizes, specific fields of study, study of only a few job characteristics which this study addresses.

\section{Literature Review}

\subsection{Theoretical Review}

The JCM model proposed by Hackman \& Oldham, portrays five center employment measurements prompting three basic mental states, bringing about business related results. Skill variety, task identity, task significance autonomy and feedback will not have uniform effects. The more of these characteristics a job has, the more motivating the job will be. The job characteristics model foresees that a person with such a job will be highly satisfied and will produce more and better work, which is better performance [11]. In this model, the main outputs which are motivation and satisfaction and are used to inform the mediating variable, motivation as well as the dependent variable, which is employee performance, as one aspects feeds into the other.

According to Herzberg, the two-factor theory differentiates between motivators that usually generate positive contentment which emanates from inherent states of the occupation itself, for example, acknowledgment, accomplishment, or self-improvement and cleanliness matters that don't give positive worker fulfillment, in spite of the fact that disappointment comes about because of their nonexistence [14]. Herzberg argued that, the term hygiene is used to mean that these are continuation factors extrinsic to the work itself and include aspects such as company policies, supervisory practices, or salary [15]. The independent variables in the study such as autonomy, feedback and skill variety are examples of motivators that will lead to employee motivation and commitment to their work. This in turn reflects on the overall performance of the employee.

\subsection{Empirical Literature Review}

In addition to the theory and models used, the authors reviewed past studies on the aspect of motivation and the relationship on job characteristics and employee performance. Previous research has shown that human resources practice (employee participation) is positively related to performance, employee productivity and satisfaction [25, 29, 31]. Motivated employees pay extra attention and time to their work, they make work as a part of their life; consider ethical responsibility and virtue to perform their tasks, take organizational goals as their own goals and feel delighted and satisfied while achieving them [26]. The studies could not however pinpoint on the key issues for employee participation and involvement [31].

In order for jobs to be effective and favorably contribute to performance of employees, job characteristics must be taken into account through understanding of the job itself and its place in the bigger work unit's work course process. Having a detailed knowledge of the tasks performed in the task unit and in the work, the manager then has numerous alternative ways to design a job. A study by Keijzers on worker motivation identified with execution of workers found that, not all discoveries in the accessible writing were reciprocal on the issue under study. A few analysts put forth opposing expressions on how outward sparks can add to representative inspiration and execution. For instance, on the point of how compensation impacts worker motivation; a few analysts contend that pay does not increment while others contend that it is the most affecting help for representatives [19]. Prior research carried out by Vroom brought about the conclusion that worker motivation and performance were uncorrelated [30].

Managerial implications for this study were that, inherent factors may cause employee motivation when they exist within the organization. However, external motivators, if absent in the company may cause lack of motivation of the employees. In view of this, it is vital that managers take into consideration both internal and external motivational factors. Supervisors must select the external motivational factors because a single factor may cause lack of satisfaction. Supervisors may also need to consider the effects of these external factors on the internal motivation.

Scholars contend that identities of employees respond contrastingly to motivational components. A few people are all the more inherently and others are all the more outwardly motivated and this causes distinctive productivity among employees. It is by and large acknowledged that a worker's productivity depends on individual components, specifically: identity, aptitudes, knowledge, experience and capacities [30].

A study by Imran, Maqbool, \& Shafique uncovered the fact that motivation had significant impact on employee performance but as well as concern for training of employees. It was found that training had no significant impact on employee performance [17]. Thus if employees are motivated towards their work, their performance will be better than those who are not motivated towards their job while training did not influence employee performance.

\subsection{Conceptual Framework}

Some research gaps that were identified included a study by Keijzers revealed that not all findings in the available literature were complementary on the issue under review in the study. Some researchers made contradictory statements 
on the fact how extrinsic motivators can contribute to employee motivation and performance. The study was based on other research findings and not an actual study. However, this study used actual employees in interview to make deductions hence was more realistic and actual [19].

In the conceptual framework below, employee motivation was used as a mediator for the relationship between job

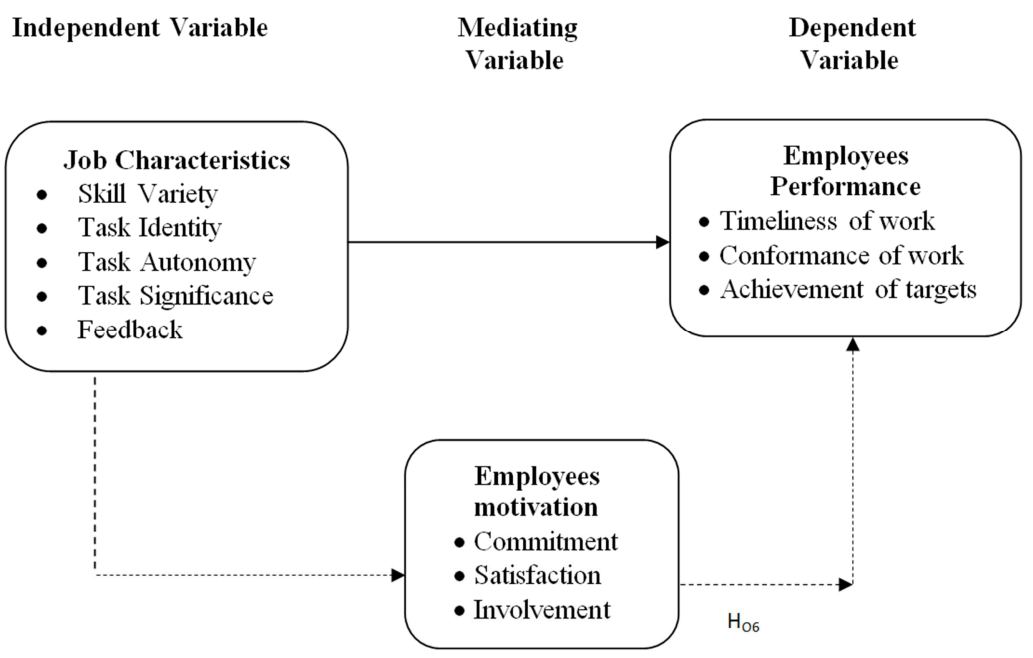

Figure 1. Conceptual Framework.

The key assumption of the study was tested by the regression analysis. One of the Hypotheses in the study included the following:

$H_{O 6}$ : Motivation does not have significant mediating effect on the relationship between job characteristics and the performance of employees among private equity firms in Nairobi City County, Kenya.

\section{Research Methodology}

This study used descriptive research design which seeks to portray an accurate profile of persons, events or situations. This design was used to examine associative relationships. The descriptive research type of design used in the study sought to portray an accurate profile of persons, events or situations. The data which was collected was then analyzed using descriptive statistics. The target population involved employees from private equity firms that are for profit and are not listed by the NSE.

The 25 firms have an estimated total of 210 employees who formed the target population for this study. The study was a census where all the known PE firms were considered and all employees were targeted. Questionnaires were used to collect primary data. The responses from the pilot test were used to test reliability. On reliability, the questionnaire was tested using Cronbach Alpha coefficient where the cut-off for Cronbach alpha was taken as a value of 0.7 .

For this study, the pilot test was within this recommendation where seven (7) questionnaires were given to employees of one of the Private Equity firms in Nairobi City County in Kenya. The results revealed that all the seven variables had an aggregate alpha value of 0.7551 for all the characteristics and employee performance. Employee motivation was operationalized through commitment, engagement and satisfaction of the employees. The relationship expected was that, if the different job characteristics are considered while designing jobs then employee performance would be enhanced while considering their level of motivation.
Mediating
Variable
Variable

twenty-five (25) items which was within the recommended range for reliability.

Table 1. Pilot Test Results

\begin{tabular}{llll}
\hline Variables & Alpha & Number of items & Comment \\
\hline Skill Variety & 0.825 & 4 & Reliable \\
Task Identity & 0.719 & 3 & Reliable \\
Task Significance & 0.734 & 3 & Reliable \\
Autonomy & 0.798 & 3 & Reliable \\
Feedback & 0.757 & 3 & Reliable \\
Motivation & 0.804 & 4 & Reliable \\
Performance & 0.726 & 5 & Reliable \\
Overall Reliability & 0.755 & 25 & Reliable \\
coefficient & & & \\
\hline
\end{tabular}

The second model sought to determine the relationship between the mediating variable (as dependent variable) and job characteristics (as the independent variable).

$$
\mathrm{M}_{\mathrm{e}}=\beta_{\mathrm{i}}+\beta_{1} \mathrm{X}_{1}+\varepsilon \mathrm{i}
$$

Where: $\mathrm{M}_{\mathbf{e}}=$ Motivation

$\varepsilon \mathrm{i}=$ Error term

$\beta_{\mathrm{i}}=$ Beta

$\mathrm{X}_{1}=$ Job Characteristics

The third model was used to establish the relationship between the independent variable (job characteristics) and the dependent variable (Employee Performance), after being the mediated effect by the mediating variable (motivation).

$$
\mathrm{Y}=\beta_{\mathrm{i}}+\beta_{1} \mathrm{X}_{1}+\beta_{2} \mathrm{X}_{2}+\varepsilon \mathrm{i}
$$

Where: $\mathrm{Y}=$ Employee Performance

$\varepsilon \mathrm{i}=$ Error term

$\beta_{\mathrm{i}}=$ Beta 
$\mathrm{X}_{2}=$ Job characteristics

$\mathrm{X}_{1}=$ Motivation

The purpose of the above model was to establish that there are relationships among the variables. This implied that if one or more of these relationships are non-significant, the conclusion is that mediation was not possible [5].

\section{Research Findings}

\subsection{Respondents Characteristics}

The researcher targeted 25 PE firms in Nairobi County in
Kenya. 210 questionnaires were distributed to the firms and were self- administered where the questionnaires were dropped and picked later. The questionnaires were given to all staff in the organizations. The researcher collected the data in the Month of June and July, 2016 where a total of 116 questionnaires were collected for analysis.

Table 2 is a tabulated representation of the biographic information of the respondents in the study by age, gender, level of education, number of years worked and the department each respondent belongs to within the organization.

Table 2. Cross - Tabulation of Biographic information.

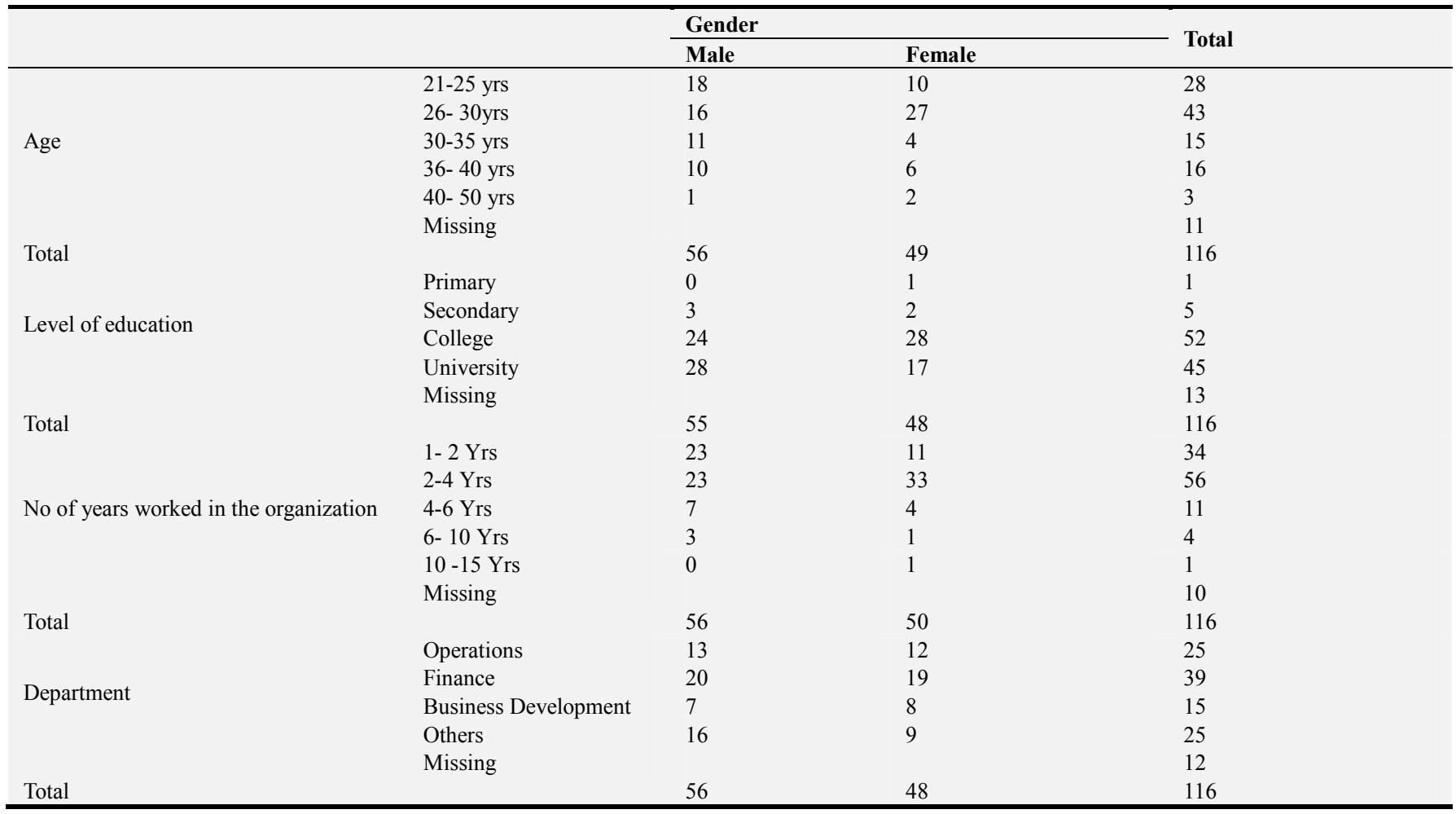

Source: Survey data (2016)

From the findings, the highest number of respondents were aged between 26-30 years, 27 of who were female and the total for this category was 43 . The age category with the least respondents was between 40 - 50 years, who had 2 female respondents and 1 male respondent. The respondents who had acquired the college level of education were the highest in number, with a total of 52. Out of these, 28 were female while 24 were male respondents. The lowest recorded level of education by the respondents was the primary level which had 1 respondent.

The findings also indicate that 56 employees had worked in their respective companies for $2-4$ years where 33 of these were female and 23 were male. Those who had worked in the respective companies for $10-15$ years were the least with only 1 respondent. According to departments, the finance department had highest number of 39, 19 of who were female and 20 were male. The department with the least number of respondents was business development which had
15 respondents, 8 of who were female and 7 male respondents. The cross-tabulation on table above summarizes these characteristics.

\subsection{Test of the Mediating Role of Motivation}

The hypothesis the study tested the mediating role of employee motivation on employee performance in Private Equity firms in Nairobi County in Kenya. Employee motivation was characterized by Commitment, satisfaction and involvement. To test for mediation, the study adopted causal steps approach that employed different models to determine mediation. The study sought to establish if there is an overall effect that can be mediated. The first model was used to estimate the relationship between the independent variable (Job Characteristics) and the dependent variable (Employee Performance).

$$
\mathrm{Y}=0.436+0.795 \mathrm{X}_{1-5}+\varepsilon \mathrm{i}
$$


There is a significant relationship between job characteristics and employee performance at a $\mathrm{P}$ value of 0.000 . The adjusted $\mathrm{R}^{2}$ of the model is 0.628 which is $62.8 \%$ meaning there is a relationship between the two variables before mediation.

\section{Discussions and Implications for Theory and Practice}

The study sought to determine the mediating effect of motivation on the relationship between job characteristics and the performance of employees among private equity firms. The study was a census where all the known PE firms that are for profit and are not listed by the NSE were considered and all employees were targeted. The objective of the study sought to establish the mediating effect of motivation on the relationship between job characteristics and employee performance in Private Equity firms in Kenya. Before mediation the adjusted $\mathrm{R}^{2}$ was lower than the adjusted $\mathrm{R}^{2}$ after mediation. The findings indicate that motivation positively affects the relationship between job characteristics and employee performance.

Previous studies indicate that having a detailed knowledge of the tasks performed in the task unit and in the work, the manager then has numerous alternative ways to design a job. This knowledge involves understanding the demands of the job. Employee involvement and engagement helps the employees increase their skill set and knowledge of the job, hence increased motivation and ultimately higher performance. According to Vroom, it is acknowledged that an employee's productivity largely depends on several individual components which include identity, knowledge, experience and capacities [30].

\section{Conclusion}

Motivation was found to affect the relationship between job characteristics and employee performance. The findings of the study showed that without mediation, the effect of job characteristics is lower than after mediation. From the findings of the study, the researcher concluded that without mediation, the effect of job characteristics is lower than after mediation. This means that employee motivation which was used as the mediator variable in the study had an influence on the effect of the relationship between job characteristics and employee performance and is an important aspect is influencing performance of employees.

\section{Recommendations}

Methods such as job rotation that can be adopted to ensure that all employees are part of the organizations entire goal as it is a form of motivation. This study recommends further research to test the impact of demographic factors such as age, education and psychological state of employees to determine their performance as a result of motivation.

\section{References}

[1] Adebayo, S. O. \& Ezeanya, I. D. (2011). Effects of job autonomy, task identity and profession among health workers in Jos, Nigeria. European Journal of social sciences, 14(1) pp. 116

[2] Adeyemo, D. A. (2015). Relative influence of gender and working experience on job satisfaction of primary school teachers. The Primary School Educators, 1, 1, 86-89.

[3] Al-Ahmadi, H. (2009). 'Factors Affecting Performance of Hospital Nurses in Riyadh Region, Saudi Arabia', International Journal of Health Care Quality Assurance, 1(22) pp. 40-54.

[4] Armstrong M. (2006). Human Resource Management Practice ( $10^{\text {th }}$ Edition), Kogan Page Limited.

[5] Baron, R. M., \& Kenny, D. A. (1986). The moderatormediator variable distinction in Social Psychological Research: Conceptual, strategic and statistical considerations. Journal of Personality and Social Psychology, 51, 1173-1182.

[6] Borman, W. C. (2004). Expanding the criterion domain to include elements of contextual performance. In N. Schmitt, W. C. Borman, and Associates (Eds.), Personnel selection in organizations (pp. 71-98). San Fransico, CA: Jossey-Bass.

[7] Choge, P. J., Chepkiyeng, F. \& Chelimo, K. K. (2014). Effects of Task Identity on Employee Motivation: The International Institute for Science, Technology and Education (IISTE). European Journal of Business and Management. USA 6(33)

[8] Cronbach, L. J. (1951). Coefficient alpha and the internal structure of tests. Psychometrika. Upper Saddle River, NJ: Prentice Hall.

[9] Deloitte, (2013). East Africa Private Equity Confidence Survey: Seeing Beyond the Waves. Retrieved from: http://www2.deloitte.com/ke on $29^{\text {th }}$ August, 2013.

[10] Gatauwa J. M. (2014). A survey of Private Equity Investments in Kenya, European Journal of Business and Management, 3(6), 2014.

[11] Hackman, J. R., \& Oldham, G. R. (1975). Development of the job diagnostic survey. Journal of Applied Psychology, 60, 159170.

[12] Hackman, J. R., \& Oldham, G. R. (1980). Motivation through the design of work: Test of a theory. Organizational Behavior and Human Performance, 16, 250-279.

[13] Hatch, M. J. \& Cunliffe, A. L. (2006). Organization Theory, $\left(2^{\text {nd }}\right.$ ed.), Oxford University Press.

[14] Herzberg, F. (1968). One more time: How do you motivate employees?

[15] Herzberg, F., Mausner, B., \& Snyderman, B. B. (1979). The motivation to work. New York: John Wiley \& Sons.

[16] Hirschfeld, R. R., Schmitt, L. P., \& Bedeian, A. G. (2002). Job-content perceptions, Performance.

[17] Imran, M., Maqbool, N. \& Shafique, H. (2014). Impact of Technological Advancement on Employee Performance in Banking Sector, International Journal of Human Resource Studies 4(1). 
[18] Kathurima, K., \& Kipanga, B. (2013). Private Equity Investments by Pension Funds in Kenya. Nairobi Act Press, Kenya, 1(1).

[19] Keijzers, B. (2010). Employee motivation related to employee performance in the organization. Journal of Organization \& Strategy, 3(6).

[20] Kemboi, A., Biwott, G., Chenuos, N., \& Rutto, A. (2013). Skill Variety, Feedback and Employee Performance. European Journal of Business and Management. The International Institute for Science, Technology and Education (IISTE): US. $5(19)$.

[21] Kothari, C. R. (2004). Research methodology, second edition, New delhi, New age international publishers.

[22] Luthans, F. (2014). Organizational Behavior. 8th ed. Boston: Irwin McGraw-Hill.

[23] Miner, J. B., Ebrahimi, B., \& Wachtel, J. M. (2012). How deficiency in management contributes to the United States' competiveness problem and what can be done about it? Human Resource Management. Fall, p. 363.

[24] Mohr, R. D. \& Zoghi, C. (2008). High-Involvement Work Design and Job Satisfaction. Industrial \& Labor Relations Review, 61(3), 275-296.
[25] Pfeffer, J. (2014). Competitive advantage through people: Unleashing the power of the work force. Boston: Harvard Business School Press.

[26] Rizwan, M. D. J. \& Khan, F. S. (2011). Relationship of Job Involvement with Employee Performance: Moderating Role of Attitude, European Journal of Business and Management, $3(8), 77-85$.

[27] Truss, C. (2012). Spinning Plates and Juggling Hats: Employee Engagement in an Era of Austerity. Wimbledon: CIPD.

[28] Utsch, A., Rauch, A., Rothfufs, R., \& Frese, M. (2006). Who becomes a small scale entrepreneur in a post socialist environment: On the differences between entrepreneurs and managers in East Germany. Journal of Small Business Management, 37, 31-42.

[29] Verma, A. (2013). Employee involvement in the workplace. In Research in personnel and human resource management, Eds M. Gunderson and A. Ponak. New Haven, CT: JAI Press.

[30] Vroom, V. H. (1964). Work and motivation. New York: Wiley.

[31] Wagner, A., J. (2014). Participation's effects on performance and satisfaction: A reconsideration of research evidence. 